\title{
Relational skills: needs experienced by nursing students ${ }^{1}$
}

\author{
Rosa Cristina Correia Lopes ${ }^{2}$ \\ Zaida de Aguiar Sá Azeredo ${ }^{3}$ \\ Rogério Manuel Clemente Rodrigues ${ }^{4}$
}

Objective: to identify the needs of nursing students in the field of relational competencies. Method: qualitative study with an exploratory-descriptive nature. The random sample included 62 students in the 2nd year of the nursing undergraduate program of a school located in the central region of Portugal. The inclusion criterion was the nonexistence of clinical teaching. Data were collected through a form designed to assess relational needs; content analysis was used to analyze data. Results: the results indicated that the students' concept of nursing care at this stage of their education is focused on the performance of nursing tasks and techniques instead of on scientific knowledge. Overall, they are aware that greater personal development and better self-knowledge are determinant for their personal and social well-being and for them to become good professionals. Conclusion: these results will support the improvement of an intervention program to be developed with these students.

Descriptors: Students, Nursing; Interpersonal Relations; Clinical Competence; CompetencyBased Education; Nursing Education Research.

\footnotetext{
${ }^{1}$ Paper extracted from Doctoral Dissertation "Competências pessoais e sociais em estudantes de enfermagem: Implicações da implementação de um programa de intervenção no Saber Fazer Relacional", presented to Instituto de Ciências Biomédicas Abel Salazar, Universidade do Porto, Portugal. Supported by Fundação para a Ciência e Tecnologia - Ministério da Ciência, Tecnologia e Ensino Superior, Portugal, - PEst-OE/SAU/ UI0742/2011.

2 Doctoral Student, Instituto de Ciências Biomédicas Abel Salazar, Universidade do Porto, Portugal. Adjunct Professor, Escola Superior de Enfermagem de Coimbra, Portugal.

${ }^{3} \mathrm{PhD}$, Assistant Professor, Instituto de Ciências Biomédicas Abel Salazar, Universidade do Porto, Portugal.

${ }^{4}$ PhD, Adjunct Professor, Escola Superior de Enfermagem de Coimbra, Portugal.
} 


\section{Competências relacionais: necessidades sentidas pelos estudantes de enfermagem}

Objetivo: identificar as necessidades manifestadas pelos estudantes de enfermagem na área das competências relacionais. Método: estudo, qualitativo com características exploratóriodescritivas, a amostra aleatória incluiu 62 estudantes do $2^{\circ}$ ano do Curso de Licenciatura em Enfermagem (Escola da Região Centro de Portugal). Considerou-se como critério de selecção a inexistência de realização de Ensino Clínico. Coleta de dados realizada por meio da Ficha de Avaliação de Necessidades Relacionais com análise de conteúdo dos dados. Resultados: indicaram que nesta fase da formação, os estudantes detêm um conceito de cuidar em Enfermagem centrado na execução de tarefas e técnicas de enfermagem em vez de na cientificidade do saber em Enfermagem e, que globalmente estão cientes que um maior desenvolvimento pessoal, um melhor conhecimento de si será determinante para o bem-estar pessoal e social e ser um bom profissional. Conclusão: as evidências permitirão aprimorar o programa de intervenção a desenvolver com estes estudantes.

Descritores: Estudantes de Enfermagem; Relações Interpessoais; Competência Clínica; Educação Baseada em Competências; Pesquisa em Educação de Enfermagem.

\section{Habilidades relacionales: necesidades sentidas por los estudiantes de enfermería}

Objetivo: identificar las necesidades manifestadas por los estudiantes de enfermería en el área de las habilidades relacionales. Método: estudio, cualitativo con características exploratoriodescriptivas, la muestra aleatoria incluyó 62 estudiantes del $2^{\circ}$ año del Curso de Licenciatura en Enfermería (Escuela de la Región Centro de Portugal). Se consideró como criterio de selección la inexistencia de realización de Enseño Clínico. Recogida de datos realizada por medio de la Ficha de Evaluación de Necesidades Relacionales con análisis de contenido de los datos. Resultados: indicaron que en esta fase de la formación, los estudiantes detienen un concepto de cuidar en Enfermería centrado en la ejecución de tareas y técnicas de enfermería en vez de en la cientificidad del saber en Enfermería y, que globalmente saben que un mayor desarrollo personal, un mejor conocimiento de sí será determinante para el bienestar personal y social y serán buenos profesionales. Conclusión: las evidencias permitirán apurar el programa de intervención a desarrollar con estos estudiantes.

Descriptores: Estudiantes de Enfermería; Relaciones Interpersonales; Competencia Clínica; Educación Basada en Competencias; Investigación en Educación de Enfermería.

\section{Introduction}

Relational and interpersonal relationship skills are considered to be the backbone of nursing care and are recognized as the competencies that differentiate excellent nursing care ${ }^{(1)}$. The acquisition of these skills is considered a progressive process, developed according to various stages: beginning, advanced beginning, competent, proficient, and expert(2). Admittedly, professional competence in nursing includes clinical and technical aspects, but relational aspects complement it. The development of professional competence is achieved only after personal competence is developed ${ }^{(1)}$. There is no doubt about the relevance of personal competence for one's personal and professional realization or of its usefulness in training or inclusion in school programs(3).

We assert that professional competence in nursing is primarily based on the nurses' personal qualities, on their personality, which determines the acquisition of education and experience. Competence in nursing comprises two essential aspects: the mobilization of personal competencies and the mobilization of different types of knowledge and know-how applied to nursing care $^{(1)}$.

The more self-knowledge a caregiver has and the more complete it is, the better the care provided(4). 
Self-knowledge (recognition of one's own limitations, emotions, being able to work with one's own emotions), respect for others, relational distance, open-mindedness, professional attitudes and behavior, attentive listening, invention, and creativity are competencies essential to the quality of nursing interventions ${ }^{(5)}$

In a clinical-reflective approach of an ecological matrix $^{(6)}$, professional competence is a result of a set of micro-interactions: with oneself (intrapersonal interaction), with others (interpersonal interaction), and with knowledge in interactive relationships (multidisciplinary interaction). Considering that people are the essence of an organization, their full involvement enables their competence to be fully used to the benefit of the organization itself, also benefiting the implementation of intervention programs ${ }^{(7)}$.

It is also important to note that the quality of care is strongly marked by the attitudes and behaviors of those providing care. Competent professional performance requires knowledge able to mobilize, integrate, and transmit knowledge acquired during the educational process $^{(8)}$, which may be enabled by the development of competencies from new pedagogical opportunities provided during initial stages of education ${ }^{(9)}$.

Specifically, nursing know-how incorporates in itself the relational know-how ${ }^{(8,10)}$, while nursing care, considered to be the special attention provided to a person requiring help, is essentially developed via an interpersonal relationship, which requires complex competencies from nurses, competencies focused on humanist principles (unity, the tendency to update one's knowledge, autonomy, progress) and on supportive relationship (acceptance, authenticity, empathy, warm respect, congruence, attentive listening)(11).

\section{Objective}

To identify the needs manifested by nursing students in the field of relational competencies.

\section{Method}

Qualitative and longitudinal study with an exploratory-descriptive approach, quasi-experimental design and triangulation of quantitative and qualitative methods, to assess the efficiency of an intervention program.

The studied population included $2^{\text {nd }}$ year students from an undergraduate nursing program taking the theoretical course in the $3^{\text {rd }}$ quarter of 2009-2010 in a college of nursing in the center region of Portugal.
There were 166 students distributed into three classes. Considering the randomization of students distributed per class, the random sample was composed of 62 students. The inclusion criterion "non-existence of clinical teaching" was considered in the sample selection.

A self-reported qualitative form addressing relational needs was used to collect data. It was composed of five open questions designed to identify relational needs expressed by the nursing students in their interpersonal and professional relationships and also their needs concerning education.

According to ethical principles, the school's president authorized this investigation and the participation of students was voluntary and confirmed by their signatures on free and informed consent forms. This study was also approved by the Ethics Research Committee (Process No. 14-12/2010) at the Research Unit in Health Sciences-Nursing (UICISA-E) of the Escola Superior de Enfermagem de Coimbra.

Data were analyzed through content analysis as a set of analytical communication techniques ${ }^{(12)}$. We note that the development of categories followed the rules: homogeneity, exhaustiveness, uniqueness, objectivity, and relevance ${ }^{(12-14)}$. The process of content analysis began with a pre-analysis of the material though skimming the answers provided to each question. The material was then explored and coded with the identification and delimitation of units, organizing categories and subcategories, through an inductive process. A panel of experts ensured the validity and reliability of content analysis.

\section{Results}

Most of the sample is composed of single (98.38\%) women (90.32\%), aged between 18 and 35 years old, though 61 participants were aged between 18 and 22 years and only one participant was 35 years old. The average age was 19.55 years old and the standard deviation was 2.163 years.

When the 62 students were asked about the skills they considered essential for the quality of nursing care, 188 units were obtained. These units were organized into two categories: professional competence, and personal and social competencies; the first is presented in subcategories and indicators.

The results presented in Table 1 show that the competencies the students considered to be essential to the quality of care delivery were: in the first place, 
the techniques and procedures (18.62\%), in the second place, supportive relationships $(18.08 \%)$, in the third place, personal and social competence (15.43\%), and only after these does scientific knowledge come (11.70\%).

A more detailed analysis shows that professional competence was organized by the subcategories Knowledge, Know-How, and Relational Know-How. The subcategory Knowledge, which includes scientific knowledge and ethics, revealed that $11.7 \%$ of the units refer to scientific knowledge and $5.85 \%$ to ethical aspects. Know-How units refer to techniques and procedures (18.62\%) and to meeting peoples' needs (6.38\%). Relational Know-How essentially refers to supportive relationships $(18.08 \%)$, to humanistic principles (11.17\%) and to communication (9.04\%) (Table 1). Personal and social competencies comprise aspects related to assertiveness, self-esteem, and the ability to adapt, among others. It represents $15.43 \%$ of the units.

Table 1 - Categories, subcategories, indicators, and units concerning competencies considered to be essential for quality nursing care from the students' perspective

\begin{tabular}{|c|c|c|c|}
\hline \multirow{2}{*}{$\begin{array}{l}\text { Categories, subcategories } \\
\text { and indicators }\end{array}$} & \multirow{2}{*}{ Units } & \multicolumn{2}{|c|}{ Quantity of units } \\
\hline & & $\mathbf{n}$ & $\%$ \\
\hline \multicolumn{4}{|c|}{ Professional Competence } \\
\hline \multicolumn{4}{|l|}{ Know } \\
\hline Scientific knowledge & $\begin{array}{l}\ldots \text { scientific... aspects... (P12) } \\
\text { It is necessary to have theoretical content... (P14) } \\
\ldots \text { the theoretical component, the basis of theoretical knowledge that grounds practice (P61) }\end{array}$ & 22 & 11.70 \\
\hline Ethics & $\begin{array}{l}\text {...responsibility... }(\mathrm{P} 1) \\
\text { Being responsible for the care delivered (P17) } \\
\text { Professional confidentiality (P47) }\end{array}$ & 11 & 5.85 \\
\hline \multicolumn{4}{|l|}{ Know-How } \\
\hline $\begin{array}{l}\text { Techniques and } \\
\text { procedures }\end{array}$ & $\begin{array}{l}\text { Well-performed techniques. (P3) (P4) } \\
\text { Competencies and technique: being able to perform nursing care procedures well ... (P6) } \\
\text {...have technical expertise and the ability to perform practice. (P18) }\end{array}$ & 35 & 18.62 \\
\hline $\begin{array}{l}\text { Meeting the needs of } \\
\text { people }\end{array}$ & $\begin{array}{l}\text {...being able to meet the patient's needs, improving their comfort and quality of life. (P6) } \\
\text {...the patients' needs should always be heeded... (P7) } \\
\text {...maintain the individual's wellbeing. (P12) } \\
\text { Meet the needs of patients. (P37) }\end{array}$ & 12 & 6.38 \\
\hline \multicolumn{4}{|l|}{ Supportive relationship } \\
\hline Relational know-how & $\begin{array}{l}\text { In my view, the quality of nursing resides not only in performing the technique but also, and not } \\
\text { less importantly, in empathy that is established at the time a technique is used. (P25) } \\
\text {...relational competencies: respect, empathy, understanding... availability (...) are relational } \\
\text { competences that most influence the patient's psychological and physical well-being. (P52) } \\
\text {...it is producing nursing care of excellence, combining empathy, observation, listening and } \\
\text { supportive relationships (P55) }\end{array}$ & 34 & 18.08 \\
\hline Humanistic Principles & $\begin{array}{l}\text { Keep in mind the fact that nursing care is provided to a human being, thus, the individual has to be } \\
\text { treated as such. Nursing care has to be directed to the individual, not to the disease... (P8) } \\
\text {...nursing care has to include the human aspect, that is, the individual should be seen as a unique } \\
\text { being, not look to the individual in his disease but also considering his emotional dimension. (P35) } \\
\text {... a holistic view of the human being in his physical, mental and emotional dimensions... (P38) }\end{array}$ & 21 & 11.17 \\
\hline Communication & $\begin{array}{l}\text { Communication skills are important (pay attention to all kinds of communication)... (P1) } \\
\text { Good communication. (P17) } \\
\text { Having good communication strategies to communicate with normal people, people with disabilities } \\
\text { and children. (P53) }\end{array}$ & 17 & 9.04 \\
\hline Inform the patient & $\begin{array}{l}\text {...at the level of the information provided to the patient/client so that he is fully informed. (P5) } \\
\text { Show some effort when teaching patients and learn more about the patient, how to support } \\
\text { patients in the best possible way. (P14) }\end{array}$ & 4 & 2.13 \\
\hline Teamwork & $\begin{array}{l}\text { Teamwork/cooperation with other health workers... (P6) } \\
\text { Team spirit so there is a healthy exchange of ideas among colleagues. (P58) }\end{array}$ & 3 & 1.60 \\
\hline \multicolumn{4}{|c|}{ Personal and social competence } \\
\hline & $\begin{array}{l}\text {...should be assertive... (P15) (P60) } \\
\ldots \text { an open mind to enable adaptation... (P21) } \\
\text { Be confident about one's knowledge (P34) } \\
\text {...tolerance... (P42) }\end{array}$ & 29 & 15.43 \\
\hline Total & & 188 & 100 \\
\hline
\end{tabular}


Table 2 shows the results of the analysis concerning the 318 units expressed by the students. They support the opinion that personal characteristics facilitate nurses' competence, especially communication skills
$(12.89 \%)$, followed by sympathy $(8.81 \%)$, tolerance $(6.92 \%)$, professionalism $(6.60 \%)$, and self-esteem/ self-confidence $(5.66 \%)$.

Table 2 - Categories, subcategories, and units concerning the personal characteristics students considered to be facilitators of nurses' competence

\begin{tabular}{|c|c|c|c|}
\hline \multirow{2}{*}{ Categories } & \multirow{2}{*}{ Units } & \multicolumn{2}{|c|}{ Quantity of units } \\
\hline & & $\mathbf{n}$ & $\%$ \\
\hline Communication & $\begin{array}{l}\text { Good communicator ... (P4) } \\
\ldots \text { able to communicate easily... (P27) } \\
\text { Ability to tailor language to the person in question (P50) } \\
\text { Observer (P19) (P20) }\end{array}$ & 41 & 12.89 \\
\hline Sympathy & Sympathy (P3) (P4) (P5) & 28 & 8.81 \\
\hline Tolerance & $\begin{array}{l}\text { Patience (P3) (P33) } \\
\text { Tolerance (P36) (P41) }\end{array}$ & 22 & 6.92 \\
\hline Organized/rigorous/professional & $\begin{array}{l}\text {...has to be an organized person (P24) } \\
\text { Rigorous (P8) } \\
\text { Hard worker (P23) (P31) } \\
\text { Competent (P8) }\end{array}$ & 21 & 6.60 \\
\hline Gentle, caring, kind, considerate & $\begin{array}{l}\text { Considerate (P10) (P56) (P60) } \\
\text { Gentle (P1) (P22) } \\
\text { Caring (P2) } \\
\text { Kind-hearted (P13) }\end{array}$ & 19 & 5.97 \\
\hline Self-esteem/self-confidence/self-assurance & $\begin{array}{l}\text { Self-confident and self-assured (P8) } \\
\text { Feel good about oneself (P19) } \\
\text {...having a good self-esteem; being self-assured and self-confident (P27) } \\
\text { Ability to deal with odd situations (P35) }\end{array}$ & 18 & 5.66 \\
\hline Understanding & $\begin{array}{l}\text { Understanding (P18) } \\
\text { Ability to understand others (P52) }\end{array}$ & 17 & 5.35 \\
\hline Responsibility & $\begin{array}{l}\text { Being responsible...(P1) } \\
\text {...responsibility... (P17) }\end{array}$ & 16 & 5.03 \\
\hline Attentive listening & $\begin{array}{l}\text {...know how to listen... (P14) } \\
\text { Ability to listen to others (P21) (P36) }\end{array}$ & 16 & 5.03 \\
\hline Humane & $\begin{array}{l}\text { Humane (P3) (P8) } \\
\text { Sensitivity (P25) (P36) }\end{array}$ & 15 & 4.72 \\
\hline Assertiveness & $\begin{array}{l}\text { Assertiveness (P45) (P59) } \\
\text { Altruism (P29) }\end{array}$ & 15 & 4.72 \\
\hline Well-disposed/extroverted humor & $\begin{array}{l}\text { Good disposition (P4) (P29) } \\
\text { Have a good sense of humor (P22) } \\
\text { Being extroverted (P5) }\end{array}$ & 14 & 4.40 \\
\hline Helpful/available & $\begin{array}{l}\text { Availability (P17) } \\
\text { Helpful (P31) }\end{array}$ & 14 & 4.40 \\
\hline Knowledge/enjoy learning & $\begin{array}{l}\text { Knowledge (P4) } \\
\ldots \text { minimally know theoretical content. (P15) } \\
\ldots \text { know exactly what to do (P24) } \\
\text { Willingness to learn (P14) }\end{array}$ & 14 & 4.40 \\
\hline Empathy & $\begin{array}{l}\text { Empathy for others (P13) } \\
\text {...establish a good relationship based on empathy (P15) }\end{array}$ & 11 & 3.46 \\
\hline Honest/true/sincere & $\begin{array}{l}\text { Honest }(\mathrm{P} 10) \\
\text { Sincere (P32) } \\
\text { True }(\mathrm{P} 40)\end{array}$ & 9 & 2.83 \\
\hline Friendship & Being a friend (P62) (P30) & 7 & 2.20 \\
\hline Perfectionism & $\begin{array}{l}\text { Perfectionist }(\mathrm{P} 7)(\mathrm{P} 2) \\
\text { Should be ....almost perfect }(\mathrm{P} 14)\end{array}$ & 5 & 1.57 \\
\hline Effort & $\begin{array}{l}\text { Interested (P2) } \\
\text { Committed (P3) } \\
\text {...has to be a dedicated professional. (P18) }\end{array}$ & 5 & 1.57 \\
\hline Presentation & $\begin{array}{l}\text { Having a good physical appearance (P39) } \\
\text { Having a good appearance (P47) }\end{array}$ & 4 & 1.26 \\
\hline Motivation & Like the occupation. (P2) (P3) & 4 & 1.26 \\
\hline Respect & $\begin{array}{l}\text { Respect } \\
\text { (P13) }\end{array}$ & 3 & 0.94 \\
\hline Total & & 318 & 100 \\
\hline
\end{tabular}


The students were also asked what professional competencies the program should enable them to acquire and 220 units were found. The units were organized into two categories (professional competence, and personal and social competence), as presented in Table 3. The results from a global analysis reveal that their opinion is that the program should enable them to perform techniques and procedures (21.36\%), enable the development of personal and social skills (16.82\%), to establish supportive relationships (15.91\%), to develop communication skills $(15.00 \%)$, and to acquire scientific knowledge (12.27\%).

It is worth noting that the results concerning the students' opinions of the professional competencies the program should enable them to acquire are related to their opinion concerning the competencies that they considered to be essential for quality nursing care previously presented in Table 1.

Table 3 - Categories, subcategories, indicators and units concerning the students' opinions regarding the professional competencies the program should enable them to acquire

\begin{tabular}{|c|c|c|c|}
\hline \multirow{2}{*}{$\begin{array}{l}\text { Categories, } \\
\text { subcategories e } \\
\text { indicators }\end{array}$} & \multirow{2}{*}{ Units } & \multicolumn{2}{|c|}{ Quantity of units } \\
\hline & & $\mathrm{n}$ & $\%$ \\
\hline \multicolumn{4}{|c|}{ Scientific competence } \\
\hline Scientific knowledge & $\begin{array}{l}\text {...well-consolidated theoretical content. (P15) } \\
\text { Scientific competencies. (P16) } \\
\text { Theoretical knowledge... (P19) } \\
\text { To develop a theoretical basis on all matters related to nursing care. (P61) }\end{array}$ & 27 & 12.27 \\
\hline Ethics & $\begin{array}{l}\text {...never neglect our responsibilities (P1) } \\
\text { Scientific competencies in regard to beliefs, cultures, ethical values, and socioeconomic status. (P7) } \\
\text { Understand ethical and deontological standards and put them into practice (P13) }\end{array}$ & 17 & 7.73 \\
\hline \multicolumn{4}{|c|}{ Competence in the delivery and management of care } \\
\hline \multicolumn{4}{|l|}{ Know how } \\
\hline $\begin{array}{l}\text { Techniques and } \\
\text { procedures }\end{array}$ & $\begin{array}{l}\text {...should provide more hours of contact in laboratories to improve techniques. (P5) } \\
\ldots \text {..enable students to perform all the procedures and techniques required... (P8) } \\
\ldots \text {...perform (nursing procedures) ... (P10) } \\
\text {...to administer medication, provide hygiene care... to suspect when something is wrong, to monitor } \\
\text { vital signs. (P53) } \\
\text { Should enable us to deal with any type of emergency ... (P58) }\end{array}$ & 47 & 21.36 \\
\hline $\begin{array}{l}\text { Meeting the needs of } \\
\text { people }\end{array}$ & $\begin{array}{l}\text { To meet the needs of people. (P20) } \\
\ldots \text {...now how to care for others, help others to fully achieve his functional competencies... (P38) } \\
\text { Meeting the needs of people. (P40) } \\
\text { Competencies that provide hygiene and comfort to the patient. (P60) }\end{array}$ & 11 & 5.00 \\
\hline \multicolumn{4}{|l|}{ Relational know how } \\
\hline Supportive relationship & $\begin{array}{l}\text { The program should also include relational competence because it is more concerned with enabling } \\
\text { students for knowledge and know-how competencies. (P6) } \\
\text { Relational competencies. (P16) (P26) } \\
\text { To be able to understand another in a deeper way. (P22) } \\
\text { Learn to listen to others (P32) } \\
\text {...know how to establish a good supportive relationship with the patient... (P52) }\end{array}$ & 35 & 15.91 \\
\hline Communication & $\begin{array}{l}\text {...should more efficiently enable communication so that it facilitates (afterwards) the dialog between } \\
\text { nurses and patients during practice...(P5) } \\
\text {...other competencies that...could deepen over the course of the program, such as communication } \\
\text { and others (P8) } \\
\text { Communication skills (P16) (P19) } \\
\text { Relationship with the patient (P9) }\end{array}$ & 33 & 15.00 \\
\hline Inform the patient & $\begin{array}{l}\text { Know to teach. (P32) } \\
\text {...being able to teach the community to promote health and education concerning healthy } \\
\text { behavioral habits. (P38) } \\
\text { Educational competencies, competence to teach and educate in health to transmit knowledge to } \\
\text { others. (P61) }\end{array}$ & 9 & 4.09 \\
\hline Teamwork & $\begin{array}{l}\text { Relationship ... nurse/other health workers (P14) } \\
\text { Teamwork (P36) } \\
\text {...keep in mind it is a profession interconnected with others... (P53) }\end{array}$ & 4 & 1.82 \\
\hline \multicolumn{4}{|c|}{ Personal and social competence } \\
\hline & $\begin{array}{l}\text { Assertiveness. (P2) (P4) } \\
\ldots \text { know to act assertively when facing diverse situations. (P44) } \\
\text { Control emotions in the field because we establish a relationship with patients and we often put } \\
\text { ourselves in their shoes or in the shoes of their families and close friends or when we are unable to } \\
\text { establish a boundary that separates emotions from home and the nursing ward (P6) } \\
\text { Social competencies (P12) }\end{array}$ & 37 & 16.82 \\
\hline Total & & 220 & 100 \\
\hline
\end{tabular}


Table 4 presents the results concerning the analysis of units reported by the students regarding the characteristics and personal competencies students need to target and change in order to become good nurses. A total of 172 units were found and reveal that the main characteristics that they need to change were communication skills (29.07\%), self-esteem (15.12\%), including aspects concerning self-esteem and self- assurance. Students also highlighted personal and social competence, and assertiveness (13.37\%).

Units concerning the development of professionalism $(8.14 \%)$, understanding $(5.81 \%)$, knowing to listen $(5.23 \%)$ and emotional competence (5.23\%), were also equally expressed by the participants; less frequently mentioned were tolerance, anxiety, and respect for others and teamwork.

Table 4 - Categories and units concerning the personal characteristics and competencies to which students deemed need special attention in order for them to become good nurses

\begin{tabular}{|c|c|c|c|}
\hline \multirow{2}{*}{ Categories } & \multirow{2}{*}{ Units } & \multicolumn{2}{|c|}{ Quantity of units } \\
\hline & & $\mathbf{n}$ & $\%$ \\
\hline Communication skills & $\begin{array}{l}\text { Know to choose the best way to transmit information to patients not to harm their } \\
\text { susceptibilities. (P2) } \\
\text { I need to improve communication, especially with people I don't know. (P5) } \\
\text {...in some situations I don't know what to say in the clinical context, this is something that I'll } \\
\text { have to work on in order to communicate with patients in more difficult situations. (P8) } \\
\text { I guess I have to improve my communication a lot... (P18) } \\
\text { Observe more. (P25) }\end{array}$ & 50 & 29.07 \\
\hline $\begin{array}{l}\text { Self-esteem/self-confidence/ } \\
\text { self-assurance }\end{array}$ & $\begin{array}{l}\text { Be more confident in my performance. (P4) (P6) } \\
\text { Also have self-esteem, because being negative may affect my competence. (P7) } \\
\text { Insecurity (P38) } \\
\text {...I'm also extremely shy and I think it often does not help me. (P18) } \\
\text {...lose my shyness... (P10) }\end{array}$ & 26 & 15.12 \\
\hline Assertiveness & $\begin{array}{l}\text { Assertiveness (P3) (P4) } \\
\text { I need to be more assertive and say 'no' in certain situations (P15) } \\
\text { Be able to stand for myself; know how to say 'no' (P36) } \\
\text { I need to work on my stubbornness; I'm too proud and I think that this feature can harm me. } \\
\text { (P8) } \\
\text { Know to respond to certain situations more correctly and not so directly. (P14) }\end{array}$ & 23 & 13.37 \\
\hline Professionalism & $\begin{array}{l}\text { Professionalism (P22) } \\
\text { Be a ... good professional (P31) } \\
\text { Responsibility (P1) (P 21) } \\
\text { Sense of responsibility (P36) }\end{array}$ & 14 & 8.14 \\
\hline Understanding & $\begin{array}{l}\text { Try to understand the patient (P9) } \\
\text { Be sensitive to the suffering of others (P51) } \\
\text { Understanding (P30) }\end{array}$ & 10 & 5.81 \\
\hline Know to listen & $\begin{array}{l}\text { Listen to others (P6) } \\
\text { Know to listen... (P14) } \\
\text { Good listener. (P30) }\end{array}$ & 9 & 5.23 \\
\hline Emotional competence & $\begin{array}{l}\text { Know to control emotions in front of patients (P4) } \\
\text { Avoid getting emotional. (P16) } \\
\text { Managing emotions (P26) } \\
\text {...manage emotions, being a little less impulsive in relation to emotions. (P28) }\end{array}$ & 9 & 5.23 \\
\hline Tolerance & $\begin{array}{l}\text { Learn to be more tolerant of others, especially when others do not have the ability or knowledge } \\
\text { to cope with their problems. (P21) } \\
\text { Be more tolerant of others. (P35) } \\
\text { I need to pay special attention to my lack of patience (P42) }\end{array}$ & 8 & 4.66 \\
\hline Anxiety & $\begin{array}{l}\text {...control my nerves in some situations (P10) } \\
\text { Need to be less anxious, nervous... (P15) }\end{array}$ & 6 & 3.49 \\
\hline Empathy & Empathy (P24) & 4 & 2.33 \\
\hline Critical thinking & $\begin{array}{l}\text { Develop greater critical thinking. (P14) } \\
\text { Critical thinking (P24) }\end{array}$ & 4 & 2.33 \\
\hline Enjoy helping others & $\begin{array}{l}\text { Be willing... to help others (P2) } \\
\text { Having a tendency to help... (P13) }\end{array}$ & 3 & 1.74 \\
\hline Respect & $\begin{array}{l}\text { Respect }(\mathrm{P} 36) \\
\text { In respecting others... (P43) }\end{array}$ & 3 & 1.74 \\
\hline Teamwork & $\begin{array}{l}\text { Know how to work within a team; cooperation (P38) } \\
\text { Be able to work within a team/cooperate (P60) }\end{array}$ & 3 & 1.74 \\
\hline Total & & 172 & 100 \\
\hline
\end{tabular}


When the students were asked about the characteristics and the personal competencies they needed to develop to improve their personal and social well-being, they reported self-esteem in $29.55 \%$ of the 132 studied units, communication skills (23.48\%), assertiveness (15.91\%) and emotional competence (12.12\%) (Table 5). Tolerance, knowing to listen and sense of responsibility were less frequently reported.

Table 5 - Categories, units concerning the personal characteristics and competencies the students need to improve their personal and social well-being

\begin{tabular}{|c|c|c|c|}
\hline \multirow{2}{*}{ Categories } & \multirow{2}{*}{ Units } & \multicolumn{2}{|c|}{ Quantity of units } \\
\hline & & $\mathbf{n}$ & $\%$ \\
\hline $\begin{array}{l}\text { Self-esteem/self-confidence/ } \\
\text { self-assurance }\end{array}$ & $\begin{array}{l}\text { Being confident (P2) } \\
\text { Work on my self-esteem. When I achieve it, I'll be able to be a better person. (P25) } \\
\text { Improve my self-esteem. (P35) } \\
\text { Self-esteem; security; self-love. (P36) } \\
\ldots \text {...lf-concept... (P55) } \\
\text { Not be shy when talking to strangers (P30) }\end{array}$ & 39 & 29.55 \\
\hline Communication skills & $\begin{array}{l}\text { Develop the ability to dialog fluidly, not feel embarrassed or afraid around people I don't know. } \\
\text { (P5) } \\
\text { Know how to start a dialogue. (P16) } \\
\text { I think I need to improve my communication with people I don't know. (P31) }\end{array}$ & 31 & 23.48 \\
\hline Assertiveness & $\begin{array}{l}\text { Be assertive. (P2) (P3) (P4) } \\
\text { Assertiveness. (P41) } \\
\text { Ability to stand up for my ideas (P41) } \\
\text { Not be so stubborn (P9) } \\
\text { Not be so direct and keep silent in some situations. (P13) }\end{array}$ & 21 & 15.91 \\
\hline Emotional competence & $\begin{array}{l}\text { Control emotions (P1) } \\
\text { Know to control my emotions in front of patients (P3) } \\
\text { Better manage emotions, feelings... (P26) } \\
\text { Facility to show feelings. (P34) } \\
\text { Improve the ability to distance myself to a professional level from the patients' problems and } \\
\text { dilemmas. (P38) } \\
\text { Empathy (P55) }\end{array}$ & 16 & 12.12 \\
\hline Tolerance & $\begin{array}{l}\text { Be more tolerant of others (P35) } \\
\text { Be more patient/tolerant. (P40) (P49) }\end{array}$ & 7 & 5.30 \\
\hline Anxiety & In my case is being... anxious... (P59) & 4 & 3.03 \\
\hline Understanding & $\begin{array}{l}\text { Perceive others better; know how to identify others' problems. (P32) } \\
\text { Maybe understand more other people's positions and opinions... (P46) }\end{array}$ & 4 & 3.03 \\
\hline Know to listen & $\begin{array}{l}\text { Be able to listen to others better. (P30) } \\
\text { Be a better listener (P44) }\end{array}$ & 3 & 2.27 \\
\hline Responsibility & $\begin{array}{l}\text { Manage to be more responsible... (P52) } \\
\text { Responsibility because I believe that I'm very inexperienced in this matter... (P58) }\end{array}$ & 3 & 2.27 \\
\hline Gentle, caring, kind & $\begin{array}{l}\text { Treat people with kindness. (P30) } \\
\text { More kindness (P45) }\end{array}$ & 2 & 1.52 \\
\hline Availability & Availability (P22) & 1 & 0.76 \\
\hline Teamwork & Teamwork (P24) & 1 & 0.76 \\
\hline Total & & 132 & 100 \\
\hline
\end{tabular}

\section{Discussion}

Highlighting the most significant results achieved in this study through the assessment of relational needs, the following conclusions were reached. Based on what the students reported as being competencies essential to the quality of nursing care, we verified that the categories (professional competence, and personal and social competence) illustrate the importance the students assign to the professional dimension (85\%) and to the intra- and interpersonal dimensions (15\%). Such findings allow us to infer that the students, at this stage of their education, do not integrate concepts advocated by some theorists, for whom the quality of nursing care is marked by the nurses' behavior( ${ }^{(8)}$ and that professional competence is only achieved after personal competence is developed(1).

Meanwhile, another piece of evidence related to the subcategories of Professional Competence is related to a greater appreciation of Know-How, due to the overvalorization of techniques and procedures at the expense of the subcategory Knowledge, especially scientific knowledge. This notion of nursing care is focused on the performance of nursing tasks and techniques instead of on scientific knowledge in nursing, essential for nurses' autonomy ${ }^{(15)}$. On the other hand, the students assigned 
significant value to the subcategory Relational KnowHow (42\%), recognizing the importance of supportive relationships, humanistic principles and communication for the quality of nursing care (10-11,16). $^{2}$

In relation to the professional competencies the program should enable students to acquire, the results are related to the competencies that are essential to the quality of nursing care previously discussed. The students, again, under-valued Scientific Knowledge and evidenced bias toward Techniques and Procedures.

These findings contradict some previous studies addressing students from different undergraduate programs where the aspect most valued is "acquisition of knowledge", indicating that teaching institutions transmit more knowledge from the knowledge scope than from the know-how, know-to-be, and know-coexist scopes $^{(17)}$.

Nonetheless, within Relational Know How, they exalt the development of competencies concerning supportive relationships and communication skills, while within the scope of Knowledge, they exalt personal and social competencies. These aspects are globally confirmed by conceptions that defend the view that competence in nursing comprises two essential aspects: the mobilization of personal competencies and the mobilization of knowledge and know-how applied to nursing care $^{(1)}$. These aspects also highlight the importance of nurses' self-knowledge that promotes skills and quality of care, that is, the better and the more complete one's self-knowledge, the better the quality of care provided ${ }^{(5)}$.

The more self-knowledge a caregiver has and the more complete it is

In relation to the personal characteristics that facilitate the competence of nurses, the students highlight communication skills but also value the ability to be tolerant, rigorous, organized, professional, understanding, assertive, and having good self-esteem and self-confidence. Overall, these findings seem to be in agreement with the idea that investing in communication skills on the part of nurses is associated with higher levels of personal growth ${ }^{(18)}$.

In regard to personal characteristics and competencies to which students need to pay greater attention in order to become good nurses, communication skills, self-esteem and assertiveness stand out. These results are consonant with those reported by studies that defend competence in interpersonal communication as an ability essential to be acquired by nurses, which enables them to provide conscientious, true and transforming care ${ }^{(19)}$. Closely related to the previous issue are the personal characteristics and competencies that students are required to develop in order to improve their personal and social well-being; they highlighted self-esteem, communication skills, assertiveness and also emotional competence.

Considering that undergraduate education should enable personal development, dimensions concerning the development of responsibility, positive relationships and cooperation emerge as having considerable relevance in empirical investigations focused on the academic success of undergraduate students(17). In other studies that are focused on acquiring knowledge in Clinical Teaching, the students' personal characteristics and maturity demonstrated in interactions ${ }^{(6)}$, self-knowledge and factors intrinsic to the individual stand out(20).

\section{Conclusion}

The content analysis concerning the opinion of students about what competencies are essential for the quality of nursing care and professional competencies the program should enable them to acquire showed a greater valorization of Know-How through an overvalorization of Techniques and Procedures at the expense of Knowledge, especially of Scientific Knowledge. The conclusion is that the concept of Nursing Care held by nursing students at this stage of their education is focused on the performance of nursing tasks and techniques instead of on scientific nursing knowledge, so essential for the autonomy of nurses and the science of nursing. It also became apparent that they attribute great value to the quality of Nursing Care and Relational Know How, especially through supportive relationships, humanistic principles and communication.

The students reported that personal characteristics are required to improve their well-being or for them to become good nurses or to facilitate nursing competencies: the development of communication skills, emotional competence, self-esteem, and assertive behavior. Finally, we conclude that the students are aware that personal development and better self-knowledge are determinant of their personal and social well-being, as well as for them to become good professionals.

\section{References}

1. Phaneuf M. Comunicação, entrevista, relação de ajuda e validação. Loures: Lusociência; 2005.

2. Benner P. De Iniciado a Perito. Coimbra: Quarteto; 2001. 
3. Falcone E. Habilidades sociais: Para além da assertividade. In: R. Wielenska. Sobre comportamento e cognição: Questionando a ampliando a teoria e as intervenções clínicas e em outros contextos. São Paulo: SET Editora; 2000. p. 1-13.

4. Crossetti M, Buógo M, Kohlausch E. Ações de cuidar na enfermagem de natureza propedêutica e terapêutica e suas interfaces com os atos de outros profissionais. Rev Gaúcha Enferm. 2000;21(1):44-67.

5. Benrerbia F, Berenguer C, Esnault O, Fischer E, Garcia

$L$, Regnard MP, et al. Construction et utilisation d'un outil permettant d'évaluer les compétences relationnelles des étudiants infirmiers en stage en psychiatrie. Rech Soins Infirmiers. 2007;90:4-14.

6. Rua M. De aluno a enfermeiro: desenvolvimento de competências em contexto de ensino clínico. [Tese de Doutorado em Ciências da Saúde]. Aveiro: Departamento de Didáctica e Tecnologia Educativa da Universidade de Aveiro; 2009.

7. Rodrigues VM, Ferreira AS. Stressors in nurses working in Intensive Care Units. Rev. Latino-Am. Enfermagem. [periódico na Internet]. julho-ago 2011 [acesso 15 dez 2011]; 19(4): [09 telas]. Disponível em: http://www.scielo.br/scielo.php?pid=S0104$11692008000100005 \&$ script $=$ sci_arttext

8. Hesbeen W. Qualidade em enfermagem: Pensamento e acção na perspectiva do cuidar. Loures: Lusociência; 2001.

9. Leonello VM, Oliveira MA. Competencies for educational activities in nursing. Rev. Latino-Am. Enfermagem. [periódico na Internet]. março-abril 2008 [acesso $15 \mathrm{dez} 2011$ ]; 16(2): [07 telas]. Disponível em: http://www.scielo.br/scielo.php?pid=S0104$11692008000200002 \&$ script $=$ sci_arttext\&tlng=pt

10. Dias MF. Construção e validação de um inventário de competências: contributos para a definição de um perfil de competências do enfermeiro com o grau de licenciado. Loures: Lusociência; 2006.

11. Lazure H. Viver a relação de ajuda: abordagem teórica e prática de um critério de competência da enfermeira. Lisboa: Lusodidacta; 1994.

12. Bardin L. Análise de conteúdo. 3ed. Lisboa: Edições $70 ; 2004$.

13. Amado J. A técnica de análise de conteúdo. Referência. 2000; 5:53-63.

14. Oliveira D. Análise de conteúdo temático-categorial: uma proposta de sistematização. Esc Anna Nery. 2008;16(4):569-76.
15. Bento MC. Cuidados e formação em Enfermagem: Que identidade?. Lisboa: Fim de Século; 1997.

16. Hesbeen W. Cuidar no hospital: Enquadrar os cuidados de enfermagem numa perspectiva de cuidar. Loures: Lusociência; 2000.

17. Jardim MJ. Programa de desenvolvimento de competências pessoais e sociais: estudo para a promoção do sucesso académico. [Tese de Doutoramento em Ciências da Educação]. Aveiro: Departamento de Ciências da Educação da Universidade de Aveiro; 2007.

18. Fernandes I. Factores influenciadores da percepção dos comportamentos do cuidar dos enfermeiros. Coimbra: Formasau; 2007.

19. Braga E. Competência em comunicação: uma ponte entre aprendizado e ensino na enfermagem. [Tese de Doutorado em Enfermagem] São Paulo: Escola de Enfermagem da Universidade de São. Paulo; 2004. 172 p. 20. Pinto C, Abreu W. A aprendizagem através das experiências clínicas. Referência. 2011; Suplemento (2): 18 . 